Special Issue on Federalism, Local Government and PolicyMaking edited by Anna Gamper and Francesco Palermo.

\title{
PARTICIPATORY DEVELOPMENT APPROACH IN LOCAL GOVERNANCE - ITS RELEVANCE FOR ECONOMIC DEVELOPMENT: A Case Study of Sri Lanka
}

\section{by Sisira Saddhamangala Withanachchi ${ }^{1}$}

University of Kassel, Kassel, Germany

Email: sisira.cmb@gmail.com

\begin{abstract}
This research paper seeks to examine to what extent local governance is effective in alleviating the vicious circle of poverty. Furthermore, traditional social relationships in Sri Lankan society are relatively and critically discussed in the notion of social capital. In Sri Lanka, local government institutions, administrative divisional secretaries, the Gramaseva division, civil society and the business community are the entities of local governance at the grass roots governance level that directly involve participation of the general public. The article studies the effect of Local Governance on poverty alleviation and observes people's direct involvement in relation to their socio economic development in the local governance political body. The Kasiwattapura at Polhena Gramaseva Division in the Matara Municipal Council is selected to study this theoretical component.
\end{abstract}

Keywords: well-being, social capital, civic engagement, deliberative decision making,

\footnotetext{
The author is currently pursuing his postgraduate degree in Global Political Economy at the University of Kassel, Germany. He has worked as an assistant lecturer in the Department of Political Science and Public Policy in the University of Colombo, Sri Lanka and as a junior researcher in the Social Scientists' Association in Sri Lanka.
} 


\section{About Federal Governance}

Federal Governance is an online graduate journal on theory and politics of federalism and multilevel governance. Its mandate is to engage the global federalism community and reach out to outstanding graduate students interested in federalism and multi-level governance. By providing a platform for graduate students to have early success in their careers, Federal Governance seeks to promote and sustain interest in federalism and multi-level governance research among graduate students. Allied with the Forum of Federations and founding partner, Institute of Intergovernmental Relations at Queen's University; Federal Governance aims to contribute to a global dialogue on federalism.

Co Chairs, Advisory Committee: Publisher:

Managing Editor:

Associate Editors:
Rupak Chattopadhyay and Christian Leuprecht Forum of Federations

(Rupak Chattopadhyay and Rod Macdonell) Annegret Eppler Joshua Cerovski, Dominic Heinz, Eva-Maria Maggi and Victoria Tait

\section{Terms of Use}

Your use of this Federal Governance article indicates your acceptance of Federal Governance's Terms and Conditions of Use, available at www.federalgovernance.ca/terms. Federal Governance's Terms and Conditions of Use provides that you may use Federal Governance content only for personal, academic and non-commercial use. Each copy of any part of this Federal Governance article must contain the same copyright notice that appears on the screen or printed page of such transmission. 


\section{Introduction}

Poverty is a national level debate in Sri Lanka. Twenty three percent of the population of Sri Lanka still lives below the national poverty line. Between 1990/91 and 2002, per capita consumption increased by $29 \%$ in real terms. The average consumption of the richest $20 \%$ of the population increased by $50 \%$, while that of the poorest $20 \%$ barely increased by $2 \%$ (Nanayakkara, 2006: 4-15).

Well-being is a normative principle of human life that indicates 'good quality' or the betterment of life. Maintaining a sufficient economic basis to ensure the securing of socio-cultural and political rights within the existing social scope is the core component of well-being. Most countries at present are implementing the method of collaborating with local governance for the prosperity of the community, while providing a sustainable solution for poverty. The social relationship through human networks and mutual collaboration are tools in modern social-based or grass roots level development programs in developing countries as well as developed countries. This application of people's participation through social capital for the development process depends on the social context. This research paper intends to discuss the engagement of the local governance process in supporting the well-being of individuals who are affected by the tsunami, especially women, by alleviating poverty.

\section{Theoretical Frame work}

\section{Opinions and Approaches to Well-being}

The views that have emerged regarding well-being differ vastly. The expectations and needs built on human diversity also differ at regional level, state level, and rural and urban social environment level. Accordingly, the criteria for measuring well-being also differ. The notion of well-being is especially different amongst the castes, geographical locations and communities in Sri Lanka. Various approaches are being used by social scientists to study well-being, which can be identified as the good life or the satisfactory life.

Jean-Yves Duclos states two main approaches. They are the welfare approach and non-welfarist approaches. The welfare approach is utilized by classical microeconomics to measure utility and happiness based on the hypothesis that individuals are rational in self-judgment for the betterment of life (Duclos, 2002: 1). The welfare approach consists of measuring indices such as per capita income and per capita production, which are used by traditional economists. This approach analyses the opportunity provided to individuals to achieve maximum utility or pleasure. Personal pleasure under this approach is being measured as a classical micro economic factor. Though the welfare approach investigates and measures income and consumption 
levels, it does not pay attention to protection, freedom, peace, health or the acquisition of non-commercial goods that are needed for well-being.

The basic needs and the capability approaches are non-welfarist approaches. The basic needs approach is a preliminary approach for identifying the level of well-being (Duclos, 2002: 2-3). A number of multi dimensional factors required for well-being are studied under the basic need - functioning approach. It is not limited to pleasure or utility. In order to have a satisfactory life, needs such as literature, appropriate health care, housing, consumption purchasing goods are required to be fulfilled. Amatya Sen observed that gaining self-respect through various activities of citizens and having an opportunity to contribute as an active citizen within the community also contribute to a life of well-being (Sen, 2004: 99-101). In the Sri Lankan context, well-being can be identified as a rather collective notion. Barrie M. Morrison noted that community organization is more institutionalized and well organized in particular directions such as achieving child and family well-being, social development and women's rights in Sri Lanka, especially after 1990 (Morrison, 2004: 35-36). As will be discussed later, this reorganization of the society can be identified as the result of traditional practices of norms and values in an agrarian society and the 'Buddhist temple based practices and values' that build an idea of community. Accordingly, the necessity for social empowerment of the individual to achieve fundamental needs is emphasized. Social empowerment means improving the capability for achieving daily needs and building social economic strength. Through this, it is expected that the capability to achieve individual needs is a criteria that must be met to attain well-being.

\section{Poverty and Poverty Alleviation}

The word 'poverty' has many characteristics and definitions. It can be studied from several perspectives and theoretical outlooks. According to the discourse analysis of Ernesto Laclau and Chantal Mouffe, the term poverty can be noted as an empty signifier. Different political and economic approaches have granted different definitions and implications for the term 'Poverty' (Howarth and Stavrakakis 2004: 9; Jørgensen and Phillips 2002: 26). Therefore, a pluralistic understanding of poverty among institutions and academics can be observed. Hence, when analyzing the definitions of poverty which are given by particular international organizations, the interests of the organizational agenda should be noted. Thus, the contextual meaning of poverty is articulated by certain political discourses.

According to Pete Alcock, poverty is a political, economic and social economic factor. Not only economic reasons, but also social factors cause the emergence of poverty (Alcock, 1993: 3). In a society in which the community is divided based on ethnicity, for example, the minority would be marginalized. Even having the government policies to protect minority rights in the country, the opportunities and social spaces for minorities would be contracted. The social pressure mounting on people due to development programs introduced by the central government or relevant local political institutions 
can cause the emergence of poverty. Social inequality emerges as a result of the social structure and caste stratification of most South Asian societies which have feudal features (Farmer, 1983: 7-8). Benefits of development or social welfare programs may be distributed on a prejudiced basis that would originate from political and personal linkages.

Lack of social production is a major reason for the socialization of poverty, which in turn leads to economic unevenness. The social production measures the overall well-being of a society. It was classified into two main categories by S. Lindenberg, namely Physical well-being and Social well-being. He identified these categories as the universal goals of the well-being of a society (Lindenberg, 1999: 61-90). These universal goals consist of five instrumental goals, which are Comfort, Stimulation, Affection, Status and Behavioral Confirmation. Equal distribution of means of production, abilities, social space, and technology are the basic factors that boost social production. Inequality of market directed distributing mechanisms also causes the creation of poverty (Harvey and Reed, 1992: 269-297). When the above scenario is analyzed in a Marxist approach, the accumulation of means and methods of economic production into the hands of a specific social group generates poverty in the society due to the unequal opportunities made available to marginalized groups in the society.

Michael Reed and David Harvey stated that the inequality of market-directed distributing mechanisms and economic unevenness also causes poverty (Harvey and Reed, 1992: 269-297). That means the economic factor plays a major role in the creation of poverty. Poverty becomes more strongly socialized because of the unavailability of proper means of income and the inadequacy of the income earned. When studying the vicious circle of poverty, it is understood that unavailability of proper income sources causes an obstruction of opportunities for investment and limits the achievement of other needs (food, housing, medicine, education) that depend upon income.

Poverty is not just about inequality. Poverty is the incapability to maintain day to day life within the existing social conditions (Sen 1993:30-31). Accordingly, poverty can be categorized as relative poverty or true poverty. Relative poverty is the diversity of various societies regarding consumption and existence. In Sri Lanka, for example, lack of a telephone does not count as poverty, because telephone is not considered a necessity. However, in a developed country, a telephone is considered as a consumer good, the lack of which is deemed as poverty. Hence, it is understood that the profile of well-being varies among different social structures.

However, true poverty is considered an absolute factor. Societies that suffer from this kind of poverty are the ones that fail to afford minimum compulsory requirements such as food, water, and sanitation (including health facilities) to maintain a fair life in any social condition. Amatya Sen stressed that a large number of people who suffer from extreme poverty are living in the South Asian region and the Sub-Saharan region. The 
majority of the communities in those regions have low individual incomes (Sen, 2004: 99-101). As a result, the other needs of such persons may be inadequately met, according to a low income. The internal policy that countries institute according to global factors is also a cause for such irregularities at the regional level. Michel Chossudovsky states that the open economy and the deployment of financial policy also affect the creation of irregularity in income distribution through such internal policies (Chossudovsky, 1991: 2527-2529). Policy changes and structural changes in regional poor countries negatively influence the people as global environmental impacts on the restructuring process.

Through the basic need-functioning approach, it can be inferred that the qualitative and quantitative changes that occur in social lives due to the alleviation of poverty is the preliminary step of a prosperous life. The initiation of programs such as empowering community cooperative development along with occupational safeguards in employment and making use of self investments are identified by S. M Miller and Martin Rein as sustainable solutions for the alleviation poverty (Miller and Rein, 1969: 16-20). For this purpose, the most suitable governance method for harnessing the community is the local governance method.

\section{Participatory Democracy and Participatory Development in the Social Capital Theory}

Representative democracy is a failure in contemporary society because representatives who are elected alienate the general public from the decision making process. This relationship can be defined as a patron client relationship. On the other hand, elitism is also another disadvantage of representative democracy. Therefore, the theory of participatory democracy has been popularized during the past few decades. Participatory democracy facilitates the active participation of individuals in public life (Schweizer, 1995: 368-369). Participation does not merely mean the presence at meetings and discussions, but also the active involvement and engagement in development and policy making functions in the governance structure. Norman Uphoff, in his analysis, points out that this inclusion of people in participatory development is approached in four ways: decision-making, implementation, benefit and evaluation (Uphoff, 1999: 215-220). The theory of social capital is a major factor in this regard.

The theory of social capital was brought to the attention of the international community in the 1990s, when international organizations stressed the need for community participation in the development process. The modern western notion of the social network was intensified with the intention of empowering the theoretical concept of Associate Life by Alexis de Tocqueville. He explains the instigation into American society in the $19^{\text {th }}$ century of an associative life. Citizens as individuals are feeble. Accordingly, civic integration through citizen committees creates the opportunity to build a strong democracy (Tocqueville, 1863: 225-226). Tocqueville stresses important concepts such as civic engagement in local democracy and civic affiliation for 
community projects (Kwak et al., 2004: 643). According to him, there was appropriate political freedom for the instigation of an associative life. Pierre Bourdieu critically conceptualized the notion of social capital in his ethnological study. . Hence, looking at the limitations of this social networking process, Bourdieu mentions either a tendency to create social injustice or social privileges (Bourdieu 2005: 2-5).

Robert Putnam states that associative improvement of civic engagement in a society causes civic conscience in community composition (Kwak et al., 2004: 643). That is, people should be psychologically assured that they are not living alone and they should feel the necessity to build corporations to achieve their own needs. Community relations networks that emerged as a result of social mobilization have led to the improvement of Social Capital (Putnam, 1995: 66). According to his argument, social capital can be applied as a social tool to achieve development. Thus, Putnam's views on social capital are integrated to launch social based development programs driven by the International Bank for Reconstruction and Development (World Bank) and other international organizations.

Mutual trust and social relationships play a major role in the establishment of Social Capital in a society. In this process, citizens should share common interests that deviate from personal interests. Due to this communality, democracy is strengthened within an organized community (Chambers, 2001: 841). Sri Lankan traditional social can be identified as a thick socially networked entity. Buddhist and Hindu social values, a traditional kinship system, and agrarian socioeconomic patterns are the elements of this thick social network. Some traditional events such as Sinhala-Tamil New Year and Kataragama festivals construct the social interactions among communities (Pieris 1976: 355-360 and Pfaffenberger 1979: 255). Furthermore, the village dwellers of Sri Lanka have traditions which have been practiced for centuries in which a strong sense of togetherness leads them to help each other on a basis of strong mutual understanding. "Aththam", "Shramadana" this sense togetherness comes into play. These institutionalized traditional programs could help maximize the potential of the available human power through social networks. (Amunugama, 1964: 137-139) However, it is necessary to build closer relationships and trust among civil groups and local government institutions existing in local democracy. In contrast, there are some social limitations in Sri Lankan traditional society. The caste system can be observed as an obstacle to formulate the solidarity in the conservative society. This issue can be observed in Sinhala and Tamil

\footnotetext{
${ }^{2}$ Aththam is the Sinhalese term that refers to team work in paddy cultivation, in which people labor with fellow paddy farmers.

${ }^{3}$ Shramadana is the Sinhalese term that refers to the participatory social programs to develop basic infrastructure facilities.

${ }^{4}$ Seettu is the Sinhalese term that refers to the micro finance network system among people without any links to banks whatsoever. It is totally dependent on the mutual trust among the members in the group. Seettu systems are practiced by farmers, government servants and small women's groups.
} 
communities. Even in the contemporary social and economic modernization process, the caste system can be observed in social practices. As a result of this social fragmentation, the mutual collaboration in villages cannot be constructed or is difficult to construct. Adam Szirmal points out that the caste system in the Asian context function as an impediment to adequately adapting human capabilities in the economic process (Szirmal 2005: 498).

Further, people are involved with local government institutions and submit their ideas for policy making, paving the way for mental satisfaction by joining in decision making for community well-being. This process emphasizes the importance of Participatory Development in the enhancement of the people's well-being, especially of those living in rural areas. Participatory development is a new approach which was introduced as an alternative to the state- oriented development discourse after the 1970s. The main focuses of Participatory Development are sustainability and self- reliance participatory development introduces a bottom-up style to the flow of benefits and decisions. This can be defined as a social-oriented development pattern (Herath 2002: 98-105). This in turn creates a new approach to development which is tailored to accelerate the improvement of self reliability in the rural society.

\section{Participatory Development in Local Governance}

Governance is a broader concept than the concept of government. The concept of government means governance by particular political institutions. The general meaning of governance can be described as control. However, scholars and international institutions have various opinions regarding the theoretical usage of this concept. Goran Hyden explains that the behavior of government institutions and groups of individuals in society is governance. The explanation given by the UN regarding governance is the actions and process that are functioning at all stages for economic, political and administrative objects (Weiss, 2000: 797).

Local governance has a broader meaning than the concept of local government institutions. According to Mila Freire, local governance is a broad concept. The formal institutions, as well as the informal social institutions such as community organizations and neighborhood accordant associations are included in this concept (Freire, 2007: 3). Further, John Harris at el explained the necessity of combining three actors. Those are local government institutions, the local business community, and local civil society (Harris, 2004: 11). However, the concept of local governance has a rather different meaning when applied to the Sri Lankan context.

Local political and administrative institutional systems are included in the local government institutions. Businessmen are included in the local business community. Voluntary societies and community groups are included in the local civil societies. However, local development and local democracy may be established with the interconnection of the above three actors. When people turn to the local development 
process, it is regarded as an improvement in the way they organize and their ability to organize.

It is the particular responsibility of local government institutions to take initial action to mobilize people or to get people to participate in such collective social organizations and groups. Local government institutions are the political institutions which have more proximity to people. Therefore, the governance institutions which consist of representatives elected by local units are the most capable institutions to identify local specialties and irregularities. Local government structures in India such as the Panchayat system are mostly engaged directly with the community for the development of rural areas. In the Indian context regarding rural economic development and people's participation, Kerala is the most suitable example to prove the effectiveness of governance that at grass roots level democracy (Jha, S.N et al, 1999: 50-51). It was the $73^{\text {rd }}$ and $74^{\text {th }}$ Constitutional Amendments that really took the Panchayat system, which was until then a highly bureaucratic institution, to the people of India. This development program was implemented through the 'Self Help Network' that consisted of grass roots community organizations and a few other voluntary associations (Jacob, 2006: 138-139). Accordingly, the actions taken to decentralize activities and resources to local government units have led to community based development at the local level and the people of the area are actively engaged in policy making and their implementation (Issac, 2001: 9). Further, the self governance power has been decentralized to local government institutions in Kyrgyzstan to take decisions according to the management of decisions and planning (Pandey and Misnikov, 2001: 226-230). Accordingly, the responsibility of acquiring development under local resources management was assigned to local government institutions and community.

In 1976, Muhammad Yunus introduced the concept of Micro Credit through Grameen Banking with the intention of alleviating the extreme levels of poverty that existed in Bangladesh. Yunus proposed the employment of local governance as an appropriate mechanism to execute his concept of Grameen Banking (Yunus and Jolis, 2007: 2-15). This revolutionized the lives of the poor people. Their dependent mentalities were replaced with productive economic goals. The considerable economic growth achieved by the area of Burichang Upazila Parishada, a constantly flooded area located in the Comilla District, bears testimony to the success of this program. An integrated community development project was put in place by the Bangladesh Academy of Rural Development. The Comprehensive Village Development Co-operative Societies that already existed in this area were utilized for the mobilization of the rural people (BARD 2010: 1-4).

Indonesia is a country formed by the combination of a massive number of islands. This very fact caused the islands lying in the peripheral areas to break away from the Jakarta central government and thus, most development plans of the central government did not reach out to many regions of the country. Participatory development programs were inaugurated with the involvement of the respective Local 
Governments in order to successfully address the poverty issues that arose as a result. The Indonesia Kecamatan Development Program, which was based on a socioreligious platform, was a key aspect in the development of the economic standards of the people at grass-roots level (Wong 2003, 1-5; World Bank, 2011).

Many steps have been taken by the aforementioned programs to empower rural societies in many ways such as building community centers, training people for self employment, generating investments through circulatory loan systems and establishing micro finance loan mechanisms. The role played by Local Government Institutions in this respect is the creation of an institutional framework by bringing together and coordinating the three key actors, NGOs, civil society and the business community to facilitate the functioning of these Participatory Development Programs. It has been a productive investment in achieving the alleviation of poverty. Social integration built on community integration with people can be identified theoretically as Social Capital. A strong Social Capital combines with the development process to alleviate poverty from the local society by making a sustainable base for well-being. The following section that refers to the theoretical and comparative discussion is dedicated to analyzing the case study which is based on Sri Lanka.

\section{Case study}

\section{Local Government Structure in Sri Lanka}

The Sri Lankan Local Governance process boasts a long and eventful history. The village has been the basic government institute since the $4^{\text {th }}$ century BC, which was the era of King Pandukabaya. "Gamika" and "Parumuka" were the names assigned to the leaders of village councils. According to Tressie Leitan, the current Sri Lankan government structure is the result of British colonialism. She further explains that the current Local Government Structure also functions within a highly centralized administrative process (Leitan, 2009: 3-4).

Three kinds of Local Government Institutions can be identified: Municipal Council, Urban Council and Pradeshiya Sabha. These are all institutionalized through central government parliament acts and ordinances.

- Municipal Council - Chapter 252 - institutionalized in large and highly urbanized areas such as Colombo (Capital city of Sri Lanka)

- Urban Council - Chapter 255 - institutionalized in smaller towns and growing urban areas.

- Pradeshiya Sabha - Act number 15 of 1987 - institutionalized in the rural and countryside areas 
The Sri Lankan Local Government system functions as a service delivery mechanism in a highly centralized government structure (Uyangoda, 2005: 341-345). Local government institutions are operating as the service delivery institutions of the central government such as collecting taxes, maintaining urban sanitary systems and engaging in minor construction work within the region. There are a number of reasons for this such as the lack of power given to local government institutions by the local government acts of Sri Lanka. They are not given authority to implement poverty relief programs. However, it can be observed that some local government institutions are creatively broadening those objectives.

\section{Functioning of Poverty Relief Programs (Pro-Poor Development- Programs) presently operating in Sri Lanka}

A number of poverty alleviation programs have operated in Sri Lanka during the recent past based on strong civil society organizations and groups, which were discussed in the social capital part. Among those programs, Janasaviya ${ }^{5}$ and Samurdhi ${ }^{6}$ and other pro-poor development programs were introduced after 1989. The positive factor of all these programs was that they were based on savings methods, giving the opportunity for self investment for the alleviation of poverty in a true manner. However, all these pro-poor development programs were implemented according to the central government's plans and programs as state-oriented development programs (Hewawitharana, 2004: 468-470). Therefore, the participation of local government institutions in Sri Lanka was hardly seen under these programs.

The central government releases financial provisions to central government agencies in different areas, namely, divisional secretariats through district secretariats. Then the officers in charge of implementing these policies report to divisional secretariats. Therefore, people become closer to divisional secretariats than to the local government institutions. However after the tsunami disaster in 2004, some local government institutions in tsunami affected areas expanded their functions towards development programs, participating with the citizens in the local government areas (Uyangoda, 2005: 341-352).

\footnotetext{
${ }^{5}$ The Janasawiya Program was introduced by the United National Party in 1989 . This was a welfare program that empowered poor people through several participatory social programs

${ }^{6}$ Samurdhi was introduced by The People's Alliance government in 1994. This welfare program also focused on poor people based on the income index. The government has been adopting the Samurdhi program as a key administrative function in most areas to empower poor people. It consists of the village banking system, the social group program, and participatory development programs.
} 


\section{Research Framework}

Research Area

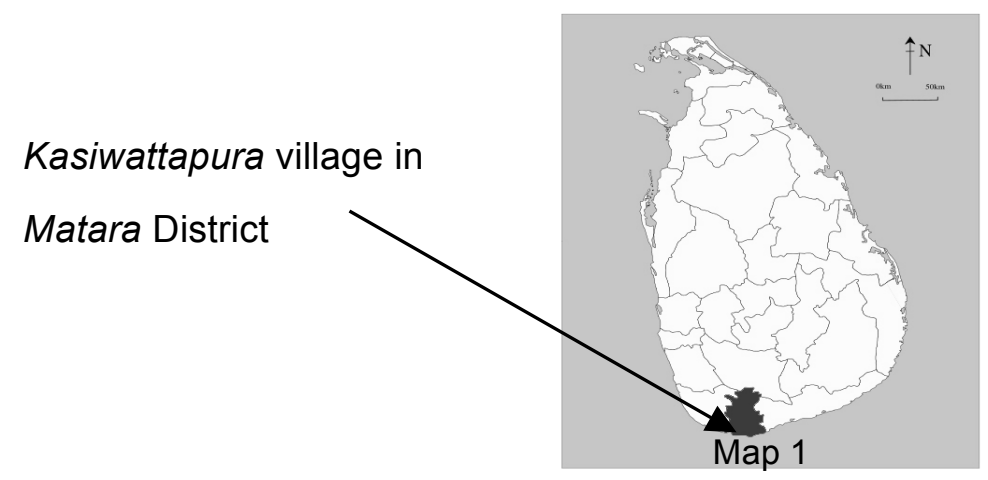

Source: Department of Census in Sri Lanka, 2009

The study area was Kasiwattapura village of Gramaseva ${ }^{7}$ division of Polhena of Four Gravest No.412 in Southern Province. The total number of families living in Kasiwattapura is 112. Polhena area is famous for a long beach, where local and foreign tourists regularly visit. Therefore, direct and indirect employment opportunities were available as a result of the presence of local and foreign tourists. All these employment opportunities were destroyed on 26 of December in 2004 due to the tsunami devastation. Three hundred twenty five people died in Polhena, which was considered as the highest number of deaths in the country. The number of persons displaced due to the tsunami was 812 .

\section{Research Sample}

A sample of 20 families in Kasiwattapura of Polhena was selected for the study. The Mayor, the commissioner of Matara Municipal Council and four officers of Kasiwattapura Jayashakthi Women Society were used as a second sample. Accordingly, within this sample there are 3 social levels that were observed.

1. General rural community

2. Officers of civil organizations

3. Government officers

\footnotetext{
${ }^{7}$ Gramaseva divisions are the smallest administrative divisions in Sri Lanka.
} 


\section{Research Methods}

Mainly, the analytical method was used for this research. Data was gathered through questionnaires, interviews and meetings with target groups. Further, the numerical data provided by the Municipal Council and the Jayashakthi Women Society was also used. It was explained on a theoretical basis by analyzing such factors and data obtained by those reports.

\section{Application of Participatory Democracy for poverty alleviation}

Kasiwattapura is a semi-urban area in Matara Municipal Council. The economic base of this area was instantaneously wiped out by the tsunami which hit Sri Lanka in 2004. Basically, there were about 20 families in which the husband, who was the family's only bread winner, was killed by the tsunami. Furthermore, there are about 31 families in the Kasiwattapura area in which the husband has left the family. Persons engaged in permanent employment are limited, as most people earn their livelihood by doing odd jobs as hired laborers. Therefore, people in Kasiwattapura require a permanent source of income. Mentioned below are the criteria for well-being that the people in the area are believed to have, which was identified through the research.

\begin{tabular}{|l|c|}
\hline \multicolumn{1}{|c|}{ Criterion } & Percentage(as per priority) \\
\hline Permanent income source & $85 \%$ \\
\hline Health facility & $45 \%$ \\
\hline Education & $20 \%$ \\
\hline Food & $25 \%$ \\
\hline
\end{tabular}

Graph 1-(Source: Based on research data 2009-August- 2010 January)

The Matara Municipal Council established the Polhena Jayashakthi Women Society from the month of October 2007. Membership of this society is limited only to women. By granting membership exclusively to women, it is hoped to empower women as positive contributors to the family. Further, it is expected by the Municipal Council to have civic affiliation to solve social and economic issues that have emerged in the area. The International Centre for Sustainable Cities (ICSC) Canada, with funding from the Government of Canada through the Canadian International Development Agency, 
launched a project to build the Women's Resource Centre in 2009 to rehabilitate the tsunami affected women in the coastal areas Matara and Moratuwa. In the Matara project, alignment with the Matara Municipal council, CAPNET organization and Sewanatha Urban Resources Center provided their joint contribution in empowering this Jayashakthi Women Society. They have launched the women's empowerment program in 3 stages.

\section{Development of livelihood}

The main intention of organizing a community for self employment was to solve the issue of finding a permanent source of income. The total number of recipient families of Samurdhi donation was 243. The Municipal Council and the Sewanatha Organization have jointly taken relevant actions to hold training programs for self employment opportunities, having consolidated the members of non recipient families. At present, about 80 families are engaged in self employment. The most prominent small scale industries are shoes production, coconut hush-related creations, sweets and agricultural products such as mushrooms, flowers. The Matara Municipal Council has taken necessary steps to arrange a market for these products made through self employment. The members of the Jayashakthi Women Society and their family members were made aware of environmental conservation by the Matara Municipal Council and it has held seminars to train them to make compost fertilizer. The garbage issue in this area is at an all time low. When compared with other areas of the city, it is almost negligible. People in the area are making fluid and solid compost, which has become a business for some in the area.

\section{Micro Credit System}

The aforementioned concept of a micro credit system was the brainchild of Muhammad Yunus of Bangladesh. Through this program, people are granted loans for daily requirements. As an initial donation, the CAPNET organization granted Rs.478, 000/to the Jayashakthi Women Society for the inauguration of their loan program. At present, the total amount of money available is Rs. 598,000/-. Loans are granted under two categories.

1. Consumption loans for daily needs

2. Loans for initiating and maintaining self employments

Before the implementation of this micro credit system, people used to obtain loans from private loan providers at $20 \%$ credit interest. Many people could not repay their loans because of the exorbitant interest rates. When they applied for loans from banks, they were requested to provide a guarantor who served in government service and the delay in issuing loans was also a major issue. Therefore, people in this area were reluctant to obtain loans. This has been a major reason for the collapse of self employment from the very beginning. 
Consumption loans were provided at a ceiling rate of Rs.500/- with a one month recovery period. Such loans were provided starting in the month of May, 2008. At present, 28 persons were granted loans of Rs.14, 000/- . Those loans were granted for the following reasons:

1. Purchasing Flour

2. Medicinal Purposes

3. Purchasing Rice (Staple Food of Sri Lanka)

4. Buying school equipment

5. Visiting relatives

The amount of Rs.20000/- was issued as self-employment loans, subject to a recovery period of 40 months. The special characteristic of this loan is that there is no exact premium and the guarantor is the husband of the eldest person in the family, who earns money.

\begin{tabular}{|l|c|}
\hline Self employment & Percentage \\
\hline Production of goods & $15 \%$ \\
\hline Production of food items & $18 \%$ \\
\hline Sales of food & $14 \%$ \\
\hline Sales of hand crafts & $20 \%$ \\
\hline Taxi & $33 \%$ \\
\hline
\end{tabular}

Graph 2-(Source: Based on research data 2009-August-2010 January)

Mr. Rohana Chaminda, who employed himself as a shoemaker with capital obtained under this loan program, is now earning a sum of Rs.2500/- per day. Mrs. Vithanage Ariyawathi has started a mobile trade stall after obtaining a loan. She was a woman, who suffered as a result of her drunken husband and son, before starting this self employment. Mrs. V Ariyawathi has managed to achieve prosperity in life. Now, she collects jack fruit and green leaves from the area, packs them and sells the produce in the town. Her daily income is about Rs.800/-. Mrs. P. V Padmalatha packs pepper and other spice items and sells them for a living. The loans required to maintain this industry were provided by the Jayashakthi Women Society. 


\section{Holding sessions for taking community based decisions and self-management}

Self management sessions are held to provide a wider space for the community to participate in policy decisions. People should be given the opportunity to participate in the governance and management process in order to maintain democracy and political equality. For this purpose, the Matara Municipal Council built a community center in March 2009 with financial assistance from the CAPNET on land in Kasiwattapura. The obstacle of holding formal meetings was overcome by this action. The Jayashakthi Women Society is holding formal meetings at present. These sessions are based on the following themes.

\section{Self management}

\section{Taking community based decisions}

Policy decision making and implementing such decisions occur with the complete intervention of the Municipal Council and CAPNET. However, during these sessions, opportunities were given to take decisions upon self consent. The banking system built by members of the Jayashakthi Women Society is presently in operation. At the community center, there is a center for selling goods produced by the rural community. Having established a coordinating center based in the community center, a trade relation network has been established that connects towns. This is an aspect of "deliberative decision making" (Harris, 2004: 11). Through this behavior, a consensus is expected with the decisions of the majority, disregarding personal and social irregularities.

\section{Issues and limitations}

Some obstacles can be observed in this process. Firstly, it is difficult to build solidarity among villagers because of the caste system. Some people who live on the other side of the main road do not participate in this program. Through the interviews, it was revealed that the reason behind the disjoint of the Jayashakthi Women Society is a caste hierarchical issue. The Matara district can be considered as a mix-caste area. The population consists of Goigama, Durawa, Karava and Halaagama castes. The dominant caste would be decided by the density of their caste in the population of the area. Michele Ruth Gamburd has also observed in her anthropological study in Naeaegama village that most of the Halaagama caste resides near the Matara City area (Gamburd 2000: 153). Some people who do not join this women association belong to the Goigama caste or Durawa caste. These two castes maintain relatively dominant positions in the social system in the Matara district. Most people in Kasiwattapura belong to the Karawa or Halaagama caste.

The second obstacle is gender issues. Some husbands or fathers do not support their wives or daughters to join or maintain active membership in the Jayashakthi Women 
Society. The patriarchic family system does not allow the active civic engagement of women. One man who was interviewed said that this Jayashakthi Women Society is an ideal place for gossip. This claim highlights the stereotypical idea in Sri Lankan traditional society that women are gossips. Furthermore, he said that the Women's Resource Centre in Kasiwattapura is a waste of time and that women neglect their household functions. However, it can be observed that some adult men are addicted to illicit alcohol. They do not give effective support for families. Some members of the Jayashakthi Women Society pointed out that these negative impacts are the obstacles that they have to overcome.

Thirdly, the Jayashakthi Women Society is currently facing a lack of business networks. This depends on the continuing support of the Municipal Council, the local business community and other institutions. Also, foreign and local tourism is one of major factor for handicraft production in the center. Some members of the Jayashakthi Women Society claimed that most shops in Matara do not buy or give space to sell their products. After establishing this project, there is a lack of supervision and support from relevant government and non-government institutions. Lack of training programs is another reason that was mentioned. This issue can be observed in many social empowerment programs in Sri Lanka which are launched by the central government, provincial governments, local governments or NGOs.

\section{Conclusion}

Several findings and conclusions have emerged through this research. The idea of well-being can be observed as a multi-dimensional factor and a definitive must in the achievement of poverty alleviation in both less developed countries and developing countries. Though there are multi-dimensional explanations for poverty, the research revealed that a permanent source of income is required in order to establish a strong foundation in life. Social capital based on social network, civic conscience and mutual trust has given rise to participatory development. It is clear that local governance is the most suitable political base to serve that purpose, for it provides opportunities to improve the potential capability of local communities by organizing and empowering them towards economic sustainability. For the achievement of Participatory Development, it is observed that the concept of governance should be inclusive of NGOs, civil society, community based organizations, informal social groups and the business community.

The Panchayat systems of India, the local government system based regionally on Upazilas in Bangladesh, the Kecamatan Development Program (run by the World Bank and Social Development in East Asia and Pacific Program with Indonesian local governments), and the Sri Lankan local government based on the Kasiwattapura case study provide proof to support the principle of proximity. This describes the close relationships of governance bodies with the people and the principle of subsidiary, 
which is based on shifting more power to the fundamental governance bodies of a country (Gilly and Wallet 2001: 554; Kaufmann 1988: 275). This could direct the community towards sustainable development and would be an approach to a successful process of alleviating poverty through the potential of the community. Local government institutions have to supervise to keep regularity.

However, the local governance structure is documented as the most suitable governing framework to empower participatory democracy in village based economic development; it is supposed to have collaboration with other government and nongovernment institutions and the business community to address the negative consequences in the local governance process. Hence, it shows that the notion of social capital in the positive sense cannot be achieved in reality while working with heterogeneous society. Therefore, Bourdieu's view that social relation and networks may cause inequality has been proven in the case study. Thus, social paradoxes such as caste system and patriarchic social system would be vital parts in restructuring the social empowerment program of incongruous societies. Government institutions or other NGOs that anticipate the continuation of their programs after launching them should provide further supervision and monitoring.

The social learning process especially needs to be developed in combination with the caste and an ethnically diverse society. In subsequent work, it would be important to explore other form of institutional arrangement or program setting in participatory development program in local governance level. These are the new challenges for community development programs in post war Sri Lankan society.

\section{Acknowledgments}

First of all, I am grateful for the useful comments on the first draft of the paper submitted to the Institute for Studies on Federalism and Regionalism in EURAC, as well as and the anonymous referee in the Federal Governance Graduate journal. Also, I am also grateful to Professor Jayadeva Uyangoda and Professor Tressie Leitan for giving their comments and guidance in the field research. I would like to show gratitude to Amanda W. Schimunek, Damien Frettsome, Siyat Gaye, Menushka Karunakalage and Thilina Madiwala for their feedback. Last but not the least, I extend my humble gratitude to all interviewees in the field who dedicated their time and allowed me to participate in their meetings. 


\section{References}

[1] Amunugama, Sarath 1964, "Rural Credit in Ceylon: Some Sociological Observation", The Ceylon Journal of Historical and Social Studies, vol. 7, no. 2, pp. 135-143.

[2] Bangladesh Academy for Rural Development (BARD) 2010, Kotbari, Comilla SSC in the Context of Aid Effectiveness: Telling the Story of Partners in SouthSouth and Triangular Cooperation Produced for the Task Team on South-South Cooperation, available at http://www.impactalliance.org/ev_en.php?ID=49119_201\&ID2=DO_TOPIC.

[3] Bourdieu, Pierre 2005, The social structures of the economy, Cambridge and Malden: Polity Press.

[4] Chossudovsky, Michel Global 1991, "Poverty and New World Economic", Economic and Political Weekly, vol. 26, no. 44, pp. 2527-2529+2531-2537.

[5] Department of Census in Sri Lanka 2009, Sri Lankan Map.

[6] Duclos, Jean-Yves 2002, "Vulnerability and Poverty Measurement, Issues for Public Policy", Social Protection Discussion Paper Series, no. 0230, Washington: Social Protection Unit, Human Development Network, The World Bank.

[7] Freire, Mila 2007, "Sustainable cities; the role of local governance in managing change", Symposium on A Global Look at Urban and Regional Governance: The State-Market-Civic Nexus, Emory University, pp. 1-12, available at http://halleinstitute.emory.edu/pdfs/Governance\%20paper.pdf.

[8] Gamburd, Michele Ruth 2000, The kitchen spoon's handle: transnationalism and Sri Lanka's migrant housemaids, New York: Cornell University.

[9] Gilly, Jean-Pierre and Frédéric Wallet 2001, "Forms of Proximity, Local Governance and the Dynamics of Local Economic Spaces: The Case Industrial Conversion Process", International Journal Urban and Regional Research, vol. 25, no. 3, pp. 553-570.

[10] Harvey, David L. and Michael Reed 1992, "Paradigms of Poverty: A Critical Assessment of Contemporary Perspectives", International Journal of Politics, Culture, and Society, vol. 6, no. 2, pp. 269-297.

[11] Herath, Dhammika 2008, Rural Development through Social Capital? An inquest on the linkage between social capital and development in war-torn village in Sri Lank, Sweden: University of Gothenburg School of Global Studies.

[12] Hewawitharana, Buddhadasa 2004, "Poverty Alleviation", in Economic Policy in Sri Lanka: Issues and Debates, ed. Saman Kalegama, New Delhi: Sage Publication, pp. 467-496.

[13] Hirst, Paul 1992, Representative Democracy and Its Limits, Cambridge: Polity Press.

[14] Howarth, David and Yannis Stavrakaki 2000, "Discourse Theory and Political Analysis", in Discourse theory and political analysis: identities, hegemonies, and 
social change, eds. David R. Howarth; Aletta J. Norval and Yannis Stavrakakis, Manchester: Manchester University Press, pp. 1-37.

[15] Isaac, T. M. 2001, "Campaign for democratic decentralization in Kerala", Social Scientist, vol. 29, no. 9/10, pp. 8-47.

[16] Jacob, Thomas 2006, "Functioning of ward committees in Kerala: A Case study", in People's Participation in Urban Development: A Comparative Study of the Working of Wards Committees in Karnataka, Kerala, Maharashtra, and West Bengal, ed. K. C Sivaramakrishnan, New Delhi: Concept Publishing Company, pp. 138-207.

[17] Jayal, Niraja Gopal and Sudha Pai 2001, Democratic Governance in India, New Delhi: Sage Publication.

[18] Jørgensen, Marianne and Louise Phillips 2002, Discourse Analysis as Theory and Method, London: Sage Publication.

[19] Kaufmann, Franz-Xaver 1988, "The Principle of Subsidiary Viewed by the Sociology of Organizations", Jurist, vol. 48, pp. 275-291.

[20] Kwak, Nojin, Dhavan V. Shah and R. Lance Holbert 2004, "Connecting Trusting and Participation: The Direct and Interactive Effect of Social Association", Political Research Quarterly, vol. 57, no. 4, pp. 643-652.

[21] Leitan, Tressie 2009, Women, Local Government and the Tsunami, Colombo: Social Scientist Association.

[22] Miller, S. M. and Martin Rein 1969, "Participation, Poverty, and Administration", Public Administration Review, vol. 29, no. 1, pp. 15-25.

[23] Morrison, Barrie M. 2004, "The challenge of Social reorganization", in Sri Lankan society in an era of globalization: struggling to create a new social order, eds. S. H. Hasbullah and Barrie M. Morrison, New Delhi: Sage publication

[24] Nanayakkara, A. G. W. 2006, Poverty in Sri Lanka - Issues and Options, Sri Lanka: Department of Census and Statistics.

[25] Noor, A. 1996. "Local Government in Bangladesh: Problems and Issue", Journal of Local Government NILG, vol.15, no. 1, pp. 15-29

[26] Oosterhout, Fon Van 2002, Moving Targets Towards Monitoring Democratic Decentralization, Amsterdam: Royal Tropical institute.

[27] Pandey, Kalyan and Yuri Misnikov 2001, "Decentralization and Community Development: Strengthening Local Participation in the Mountain Villages of Kyrgyzstan", Mountain Research and Development, vol. 21, no. 3, pp. 226-230.

[28] Pfaffenberger, Bryan 1979, "The Kataragama Pilgrimage: Hindu-Buddhist Interaction and its Significance in Sri Lanka's Polyethnic Social System", The Journal of Asian Studies, vol. 38, no. 2, pp. 253-270.

[29] Pieris, Ralph 1976, Social Development and Planning in Asia, New Delhi: Shakti Malik.

[30] Putnam, Robert D, 1995, 'Bowling Alone: America's Decline Social Capital', Journal of Democracy, vol. 6, no. 1, pp. 65-78. 
[31] Sen, Amatya 2004, Development as Freedom, Oxford University Press.

[32] Sen, Amartya, 1993, 'Capability and Well-being', In Nussbaum Martha Craven and Amartya Kumar Sen (ed.), The Quality of life World, Oxford: Oxford press, pp. 30-53[33] Schweizer, Stewen L. 1995, "Participation, Work Place Democracy and the Problem of Representative Government", Polity, vol. 27, no.03, pp. 359-377.

[34] Szirmal, Adam 2005, The Dynamics of Socio-Economic Development: An Introduction, Cambridge: Cambridge University Press.

[35] The World Bank Group, 2011, Indonesia Kecamatan Development Program, available at http://go.worldbank.org/9RCD9UBX40 (Accessed 19 July 2011).

[36] Tocqueville, Alexis de 1863, Democracy of America, translated by Gerald Beven, 2003, London: Penguin Books.

[37] UNDP Report, 1997, Decentralization and Democratization, New York: UN office.

[38] Uphoff, Norman 1999, "Understanding Social Capital: Learning from the analysis and Experience of Participation", in Social Capital: A Multifaceted Perspective, eds. Partha Dasguptha and I. Serageldin, Washington: World Bank, pp. 215-252.

[39] Uyangoda, Jayadeva 2005, "Ethnic conflict, the state and the tsunami disaster in Sri Lanka", Inter-Asia Cultural Studies, vol. 6, no. 3, pp. 341-352.

[40] Weiss, Thomas G. 2000, "Governance, Good Governance and Global Governance: Concept and Actual Challenges", Third Word Quarterly, vol. 21, no. 5 , pp. $795-814$.

[41] Wong, Susan 2003, "Indonesia Kecamatan Development Program: Building a Monitoring and Evaluation System for a Large-Scale Community-Driven Development Program Environment and Social Development", Unit East Asia and Pacific Region Discussion Paper, available at http://siteresources.worldbank.org/INTINDONESIA/Resources/Social /KDPM\&paper.pdf (Accessed 19 July 2011).

[42] Yunus, Muhammad and Alan Jolis 2007, Banker to the poor: micro lending and battle against world poverty, USA: Public Affairs Publication. 